\title{
A Competition State Perspective on the Development of Swedish Policies for Internationalisation of Higher Education and Research 1960s-2010s
}

\begin{abstract}
Andreas Akerlund
Abstract - This article is an historical analysis of Swedish policies for internationalisation of higher education and research from the 1970s and onwards. The analysis is carried out against the theoretical backdrop of the competition state, as a type of state reformulating and restructuring the relation between the national and international during the second half of the twentieth century with the aim of making society fit for international competition. Focussing on arguments as to why Swedish universities need to be internationalised, how this should be done and which parts of higher education that should be internationalised, the article shows the development of Swedish internationalisation policies, starting in the 1960s and -70s where focus was on international solidarity, inward student mobility and the internationalisation of teaching. In the 1980s and -90s the idea of a knowledge driven economic development was the central paradigm, resulting in a stronger focus on research and international research collaboration. To this the 2000s and -10s added a focus on ingoing mobility, both as a source of revenue through tuition fees, and a way to recruit skilled labour.
\end{abstract}

Keywords • internationalisation, internationalisation policy, competition state, student mobility

\section{Introduction: National and international in higher education and research}

The history of higher education and research contains an obvious tension between the national and the international. The university and the academic community are often pictured as inherently international if not cosmopolitan as visible in several studies on traveling scholars, academic mobility and the circulation of knowledge. ${ }^{1}$ At the same time the roots of the modern research university lie in the nationalisation of this institution as it grew more and more dependent on state funding. Various scholars have pointed to the professionalisation of the academic taking place in Germany in the nineteenth century with the creation of scientific disciplines and the creation of the academic career and the professorial corps, all made possible through government funding as the professors were given the status of civil servants. ${ }^{2}$ Universities

1 For example Jan Sundin, Främmande studenter vid Uppsala universitet före andra världskriget: En studie $i$ studentmigration (Uppsala: Uppsala universitet, 1973); Sverker Sörlin, De lärdas republik: Om vetenskapens internationella tendenser (Malmö: Liber-Hermods, 1994); Terri Kim, "Shifting Patterns of Transnational Academic Mobility: A Comparative and Historical Approach," Comparative Education 45, no. 3 (2009); Global Exchanges: Scholarships and Transnational Circulations in the Modern World, edited by Ludovic Tournès and Giles Scott-Smith (Oxford: Berghahn, 2018).

2 Joseph Ben-David and Awzaham Zloczower, "Universities and Academic Systems in Modern Societies," in Joseph Ben-David, Scientific Growth: Essays on the Social Organization and Ethos of Science, edited by Gad Freudenthal (Berkeley: University of California Press, 1991), 127-39; Björn Wittrock, "The Modern University: The Three Transformations," in The European and American

Andreas Åkerlund is Associate Professor of History at the Department of Historical and Contemporary Studies at Södertörn University, Sweden.

Email: andreas.akerlund@sh.se 
have ever since been a truly national project, crucial in educating national elites and creating and defining national identities while at the same time pursuing specialised research in ever narrowing scientific fields. Björn Wittrock concludes that "[...] universities form part and parcel of the very same process which manifests itself in the emergence of an industrial economic order and the nation-state as the most typical and most important form of political organisation." ${ }^{3}$ The development towards providing higher education for ever larger groups of the population and the 'democratisation' of the university after world war two can be understood as a part of this national project. ${ }^{4}$ At the same time the twentieth century saw an increase in academic mobility and mobility programs as well as other forms of international collaborations ${ }^{5}$, illustrating that universities and research facilities in spite of their nationalisation had never ceased to be cosmopolitan milieus and important nodes in the global circulation of knowledge. Jürgen Enders has summarised this development like this:

The contemporary university was born of the nation state, not of medieval civilisation,
and it was only in the nineteenth and twentieth centuries, following the establishment
of clear national economic interests, that universities acquired their identification
with science and technology. Their regulatory and funding context was, and still is,
national; their contribution to national cultures was, and still is, significant; students
tended to be, and still are, trained to become national functionaries; and universities
played, and still play, a considerable role in what some have called the military-indus-
trial complex of nation states. In this perspective, they are very much national insti-
tutions. It is appropriate, therefore, to see current trends as part of a process by which
national systems of higher education are being challenged by new forces of interna-
tionalisation. Universities are thus objects as well as subjects of "internationalisation"
or "globalisation". They are affected by and at the same time influence these processes.

Enders description of the current trends in 2004 as a situation where national systems were being challenged by internationalisation illustrates well that although higher education and research historically always have had international or cosmopolitan aspects, recent history and processes of globalisation are something qualitatively different. To understand this, it is important to notice that internationalisation

University since 1800: Historical and Sociological Essays, edited by Sheldon Rothblatt and Björn Wittrock (Cambridge: Cambridge University Press, 1993), 310.

3 Wittrock (1993), 305

4 Walter Rüegg, "Chapter 1: Themes," in A History of the University in Europe: Volume IV Universities since 1945, edited by Walter Rüegg (Cambridge: Cambridge University Press, 2011), 13-14.

5 See for example Walter Johnson, The Fulbright Program: A History (Chicago: University of Chicago Press, 1965); Volkhard Laitenberger, Akademischer Austausch und auswärtige Kulturpolitik: Der Deutsche Akademische Austauschdienst (DAAD) 1923-1945 (Göttingen: Musterschmidt, 1976); Gerald Jonas, The Circuit Riders: Rockefeller Money and the Rise of Modern Science (New York: Norton, 1989); Karl-Heinz Füssl, "Between Elitism and Educational Reform: German-American Exchange Programs, 1945-1970," in The United States and Germany in the Era of the Cold War, 1945-1990: A Handbook, edited by Detlef Junker (West Nyack: Cambridge University Press, 2004); Olof Ljungström, Ämnessprängarna: Karolinska Institutet och Rockefeller Foundation 19301945 (Stockholm: Karolinska institutet University Press, 2010); Chay Brooks, “The Ignorance of the Uneducated': Ford Foundation Philanthropy, the IIE, and the Geographies of Educational Exchange," Journal of Historical Geography 48 (2015).

6 Jürgen Enders, "Higher Education, Internationalisation and the Nation-State: Recent Developments and Challenges to Governance Theory," Higher Education 47, no. 3 (2004), 364-65. 
of higher education can be understood in two ways. On the one hand there is a descriptive use often defined as "the process of integrating an international, intercultural or global dimension into the purpose, functions or delivery of post-secondary education."7. On the other hand, its meaning is by no means neutral in discussions on the higher education aims and ideals, with a higher degree of internationalisation being regarded as a desirable development to pursue and actively work for. Thus the term has a double function. It is both analytical, describing the ongoing process of integrating an international dimension into higher education and research, and a normative one, with any movement towards adding international dimensions being declared as per se progressive and desirable. ${ }^{8}$ As a political buzzword, internationalisation is especially important at the national level, both as a rhetorical tool for raising funds or political support, and as an umbrella term for a variety of politically desirable reforms. In this article focus is on this normative and policy-creating use of internationalisation.

In his article Enders pictures globalisation as a phenomenon challenging the idea of the nation state while the state at the same time has been crucial for implementing "global processes." Saskia Sassen argues in a similar manner and refers to the role of the state in relation to globalisation, as an "interface between national and supranational forces." ${ }^{\prime 10}$ It is therefore reasonable to argue that in order to understand national university policies in general it is important to consider what kind of nation state we are dealing with.

This perspective has been present in Swedish research on the relation between the modern state and science. Aant Elzinga for example has showed that the establishment of a Social Democratic Welfare state after World War II meant a notable shift in research policy and the organisation of higher education and research. ${ }^{11}$ Olle Edqvist has in a similar manner investigated the transformation of Swedish science and the international arena in the 1990s. ${ }^{12}$ Internationalisation as a government policy is briefly mentioned in Sverker Sörlins book on the international tendencies of science, but not analyzed in depth. He does however comment that government supported internationalisation is a new phenomenon for the late twentieth century. ${ }^{13}$

In this article I will argue that in order to understand not only the establishment of internationalisation policies, but also the way such policies are constructed and

7 Jane Knight, "Internationalization Remodeled: Definition, Approaches, and Rationales," Journal of Studies in International Education 8, no. 1 (2004), 11.

8 Peter Scott, "Massification, Internationalization and Globalization," in The Globalization of Higher Education, edited by Peter Scott (Buckingham: Open University Press, 1998); Donald Broady and Mikael Börjesson, "How to Investigate Cross-Border Phenomena: Some Conceptual and Terminological Issues," Paper presented at Power, Cosmopolitanism and the Transformation of European Elites, Trinity College Dublin, June 8-9, 2015.

9 Enders (2004), 369.

10 Saskia Sassen, A Sociology of Globalization (New York: W.W. Norton, 2007), 49.

11 Aant Elzinga, "Universities, Research and the Transformation of the State in Sweden," in The European and American University since 1800: Historical and Sociological Essays, edited by Sheldon Rothblatt and Björn Wittrock (Cambridge: Cambridge University Press, 1993).

12 Olle Edqvist, Gränslös forskning: Om internationaliseringen av svensk forskning (Nora: Nya Doxa 2009).

13 Sörlin (1994), 255-57. 
implemented, it is important to analyse their establishment and development towards the backdrop of a theory of how the modern state works in a globalised environment. The idea of the competition state provides such a theoretical frame, providing a new view on the state-higher education relationship in the modern era. Being a small industrialised country with a large higher education and research-sector and a very export dependent economy, Sweden is a good case for studying the relationship between the competition state and the establishment and development of internationalisation policy.

As will be visible throughout the article the idea of actively internationalising higher education and research has its proper history as rationales as to why work for to enhance international contacts and perspectives have shifted over time. This article is an analysis of the establishment of and the shifts in the Swedish internationalisation policy from the late 1960s until the 2010s. Focus will be on the arguments brought forth in policy documents, government investigations as well as by other actors within the field to why Swedish universities need to be internationalised. What has been presented as the main reasons for internationalisation? And how can we understand this development in the light of a general development in state functioning from the traditional welfare state to the present-day competition state?

\section{The competition state}

As briefly mentioned above the policies aiming at the internationalisation of higher education and research need to be related to more profound changes in the international environment and to the attempt of modern states to deal with global processes. The competition state is the adaption of the state to globalisation, understood as ongoing structural changes in the economy and the international institutional framework on a global level. In making society "fit for competition" many key concepts of the Keynesian welfare state are being abandoned or reformed:

While the mission of the welfare state had been to protect national society from excessive competition by controlling cross-border economic transactions, by granting social rights an protection and by nationalizing key public services, the competition state pursues 'increased marketization'. It liberalizes cross-border movements, re-commodifies labor and privatizes public services. ${ }^{14}$

This definition of the competition state by Philipp Genschel and Laura Seelkopf makes clear its differences compared to the Keynesian welfare state. The competition state prioritises microeconomic efficiency over managing the macroeconomy and it is relying on market mechanisms while avoiding market interventions. It also differs from the traditional welfare state since it prioritises the commodification of labour through active labour market policies such as subsidised employments, and the privatisation of services. It also abandons the old nation state idea of national unity through economic coherence and a common identity or culture. The openness towards international markets and global flows of capital, workers and goods goes hand in hand with a declared indifference towards race, religion, or gender. Diversity

14 Philipp Genschel and Laura Seelkopf, "The Competition State: The Modern State in a Global Economy," in The Oxford Handbook of Transformations of the State, edited by Stephan Leibfried et al (Oxford: Oxford University Press, 2015), 237. 
itself is thus declared a productive resource. ${ }^{15}$ This is commented by Philip G. Cerny, who means that this development might lead to a decline of national unity and to societies abandoning the idea of a common good on state level. Globalisation, he concludes, might in some regards not lead to a new world order, but to tribalisation and a new world disorder. ${ }^{16}$ Another result of globalisation and the transformation towards a competition state is the decline of state sovereignty. International trade treaties and the constant risk that mobile capital leaves the country makes it hard for governments to pursue protectionist or decommodification politics. ${ }^{17}$

As noted by Cerny this restructuring of the state does not lead to less state or a decline of state action. Instead it seems to necessitate "intervention and regulation in the name of competitiveness and marketisation." ${ }^{18}$ These regulations often aim at restructuring the relation between the domestic and the foreign:

\begin{abstract}
[T]he state still has a major national role to play, but that role is increasingly to expose the domestic to the transnational, to prise open the nation-state to a globalizing world, in the interest of ensuring that citizens keep up with the multiple pressures and demands of that increasingly integrated and interdependent political, economical and social ecosystem. The foreign or external is no longer external or 'outside'. It is internalized in the very way the state operates and people interact politically, economically and socially from the local to the global levels. ${ }^{19}$
\end{abstract}

\title{
Methodological considerations and sources
}

One of the methodological problems when investigating internationalisation is the variety of practices and policy areas which are part of internationalisation efforts at a given time in history. To the existing practices we can count various forms of mobility (student, researcher, teacher, administrator), or international collaborations on different levels, from researcher over institutional to national. One could also mention implementing an international perspective in teaching under the concept internationalisation at home, or other forms of international collaborations, such as textbook revisions or international educational tuning or the alignment of curriculum to a common standard such as the Bologna process.

More interesting for a study on internationalisation policy than these various practices - which will differ depending on the institutional and economical frames of higher education on a national level—are instead the intended outcomes. Why was and is internationalisation pursued? - or as Edwin Starr could have formulated it back in 1970: "Internationalization, what is it good for?" In order to answer this question, the arguments need to be systematised.

In his Internationalization of Higher Education in the United States of America and Europe Hans de Wit presents various rationales behind the internationalisation

15 Genschel and Seelkopf (2015), 239.

16 Philip G. Cerny, "Paradoxes of the Competition State: The Dynamics of Political Globalization," Government and Opposition 32, no. 2 (1997), 255-56.

17 Genschel and Seelkopf (2015), 240.

18 Cerny (1997), 251.

19 Philip G. Cerny, “The Competition State Today: From Raison d'État to Raison du Monde," Policy Studies 31, no. 1 (2010), 6. 
of higher education. ${ }^{20}$ Although being on a high level of abstraction, his model is a helpful tool when it comes to identifying and classifying the arguments used within the policy and practice of internationalisation. According to de Wit the rationales can be divided into four different groups as shown in table 1.

Table 1. Rationales of internationalisation

\begin{tabular}{|c|c|c|c|}
\hline 1. Political rationales & 2. Economic rationales & 3. Cultural rationales & 4. Academic rationales \\
\hline Foreign Policy & $\begin{array}{l}\text { Growth and } \\
\text { Competitiveness }\end{array}$ & Culture promotion & $\begin{array}{l}\text { International Dimension } \\
\text { to Research and Teaching }\end{array}$ \\
\hline National Security & Labor Market & Individual development & $\begin{array}{l}\text { Widening the academic } \\
\text { Horizon }\end{array}$ \\
\hline Technical Assistance & $\begin{array}{l}\text { National Educational } \\
\text { Demand }\end{array}$ & & Institution-building \\
\hline $\begin{array}{l}\text { Peace and Mutual } \\
\text { Understanding }\end{array}$ & $\begin{array}{l}\text { Marketization / } \\
\text { Education as commodity }\end{array}$ & & Profile and Status \\
\hline \multirow{2}{*}{$\begin{array}{l}\text { National and Regional } \\
\text { Identity }\end{array}$} & & & Enhancement of Quality \\
\hline & & & $\begin{array}{l}\text { International academic } \\
\text { Standards }\end{array}$ \\
\hline
\end{tabular}

Based on Hans de Wit, Internationalization of Higher Education in the United States of America and Europe: A Historical, Comparative and Conceptual Analysis (Westport: Greenwood Press, 2002), 8599. The names of the various aspects of the rationales have in some cases been altered for the sake of clarification.

The aspects presented in table 1 under each rationale are to be understood as examples and might not all be visible in the empirical material. The model of de Wit will be used throughout the article to highlight dominating themes as well as changes in internationalisation rationales in Swedish internationalisation policy over time. It also hints at the variety of intertwined political, economic, cultural and scientific rationales driving internationalisation in general. The fact that internationalisation has been and still is driven by such distinct forces as foreign and security policy, inner-academic rationales of communication and status or economic and occupational regards makes it especially interesting to relate the shifts in internationalisation policy to more general changes in how the modern state handles the international environment.

The sources used in this article are primarily parliamentary inquiries, so called SOU (Statens offentliga utredningar), or policy documents and reports emanating from government agencies. Supplementary material consists of conference reports or other publications on internationalisation. The material has been analysed using the rationales from Hans de Wit discussed above, in order to understand which areas of higher education and research that were prioritised and to what end internationalisation was to be carried out during the investigated time period. The main limitation of this material is that it only permits answering questions related to policy. It cannot grasp the actual internationalisation measures in the higher education sector, nor the general historical debate on why and how Swedish higher education and research should be internationalised.

20 Hans de Wit, Internationalization of Higher Education in the United States of America and Europe: A Historical, Comparative and Conceptual Analysis (Westport: Greenwood Press, 2002), 85-99. 


\section{0s: International perspectives and international solidarity}

If we are to pin down the start of Swedish internationalisation as the point in time when the concept of internationalisation is first formulated as a policy object in Sweden, then internationalisation started at the beginning of the 1970s with the University inquiry of 1968 (1968 års utbildningsutredning U68) and the internationalisation committee of the state agency for higher education (Universitetskanslersämbetet UKÄ).

Universities international contacts had of course been thematised before. Discussions on the usefulness of educational exchanges or the knowledge of foreign languages or cultures are old topics in higher education and research and state or private funding of these activities go back at least to the end of the $1800 \mathrm{~s} .{ }^{21}$ But internationalisation as a concept, a process and a desirable goal for higher education appeared around 1970 in the Swedish context. In this period internationalisation was strongly related to the idea of international solidarity, and the development of the underdeveloped world.

In a first short report the U68 committee presented the aims, which it considered crucial for higher education, and already here internationalisation was strongly related to the relationship between "developed" and "underdeveloped" countries. In the future one could, according to U68, "count with a conscious will to international equalization, contact and solidarity."22 "The report consequently discussed the need for education on the conditions of the poorer countries within a range of professions, such as engineers or medical personnel only to close this section with the following appeal:

In a situation where the welfare gap between industrialized countries and underdeveloped countries is growing it is urgent to raise the question of the role of education in a conscious international politic for solidarity and equalization. ${ }^{23}$

In its final report, published in 1973, U68 returned to internationalisation as one of five main aims, of higher education, the other four being personal development, welfare, democracy, and social change. The inquiry emphasised that:

[...] the community that Swedish education relates to should not be reduced to the Swedish society. A developed solidarity and a broad frame of reference related to it must also concern the world society. The internationalization of education should not only treat conditions in Nordic and other European countries. It can in many cases be especially motivated to pay attention to the conditions in non-European states of which many will have a great importance for the future of human culture. ${ }^{24}$

21 See i.e. Henrik Brissmann, Mellan nation och omvärld. Debatt i Sverige om vetenskapens organisering och finansiering samt dess internationella och nationella aspekter under 1900-talets första hälft (Lund: Lunds universitet, 2010).

22 U68, Mål för högre utbildning: Diskussionsunderlag utarbetat inom U 68 (Stockholm: Norstedt, 1969), 57. It should be noted that earlier investigations into U68 did not pay attention to internationalization being formulated as one of the aims of higher education. See for instance Bo Lindensjö, Högskolereformen: En studie i offentlig reformstrategi (Stockholm: Stockholms universitet, 1981), 107-23.

23 U68 (1969), 59.

24 SOU 1973:2: Högskolan: betänkande av 1968 års utbildningsutredning (Stockholm, 1973), 49. 
The suggestions of U68 had to be concretised and this was done mainly through the state agency for higher education, UKÄ, and the "internationalisation inquiry" conducted by the agency. Starting its work in 1972, the inquiry was to give recommendations on how internationalisation could be promoted. The inquiry itself formulated two main internationalisation motives: a general motive related to the importance of education for personal development and general knowledge of the world, and a labour market motive, related to the formation of professionals working abroad, or in certain domestic sectors. ${ }^{25}$ The inquiry reports were the first Swedish examples of what internationalisation should mean in practice and according to the instruction given to the inquiry it was to investigate three types of needs: 1 . Education for working abroad, 2. Specific knowledge of foreign conditions for Swedish professions such as teachers, journalists, state clerks or tradesmen, 3. General orientation on foreign conditions. The motivation as stated by the agency is highly interesting, as it stressed that Swedish official development assistance or participation in international collaboration had made the inquiry necessary. ${ }^{26}$ Here international solidarity was not only understood as a matter of raising the consciousness about foreign conditions amongst Swedish teachers and students, but also about educating for the practical needs of international missions.

In the final report the inquiry made a number of suggestions. Most of them concerned the content of the curriculum. It treated international perspectives in the school system in general and the need for further training of school teachers, internationalisation of higher education curricula and course content as well as the need for enhanced teaching of foreign languages focusing technical or professional language. ${ }^{27}$ The need for general funding of internationalisation was also thematised as well as in- and outgoing mobility. Mobility in general was motivated with the general need for international contacts to achieve the goals of the inquiry: "Vivid contacts with research and education in other countries should affect the educational planning in the direction of increased consideration of other starting points than specifically Swedish ones." ${ }^{28}$ The inquiry also mentioned the importance of international contacts for the renewal of teaching and research as well as their importance for enhancing international understanding and personal development. As main reasons for incoming mobility, specifically for receiving foreign students the inquiry mentioned international solidarity and responsibility, the question of reciprocity as well as the creation of an international environment at the Swedish universities. ${ }^{29}$

One result of the internationalisation inquiry was that internationalisation was made one of two "social goals" within the university reform of 1977. The law now stated that higher education should "promote understanding for other countries and international conditions." ${ }^{30}$ The view on internationalisation as mainly a question

25 UKÄ, Att internationalisera universiteten: utgångspunkter, riktlinjer och frågeställningar för en internationalisering av universitetsutbildningen. Betänkande III från UKÄ:s internationaliseringsutredning (Stockholm: UKä, 1973), 32-33.

26 Ibid., 9.

27 UKÄ, Utbildningens internationalisering: Slutbetänkande från UKÄ:s internationaliseringsutredning (Stockholm: UKÄ, 1974), chap. 3, 4, 6, 7.

28 Ibid., 137.

29 Ibid., 149.

30 Proposition 1976/77:59: Om utbildning och forskning inom högskolan m.m., 3. 
of integrating international perspectives, especially related to the developing world, into the curricula, seems to have been adapted within teacher education and the secondary school. It is interesting to note that the development agency SIDA was involved in producing material for concretising the overarching goals for internationalisation in secondary schools in 1977, and that a 1985 survey on internationalisation in teacher education in Linköping show that the interviewees were very concerned with creating understanding for other cultures or global peace. ${ }^{31}$

The idea of internationalisation presented in the U68 and the UKÄ internationalisation inquiry contained aspects of all four rationales present in the de Wit model, although with very different emphasis. Peace, mutual understanding and technical assistance were central aspects in the argumentation, and they all clearly belong in the realm of foreign policy, whereas another central aspect, that of individual development, belongs to the cultural rationales. Academic rationales were less central. The international dimension to teaching was the most prominent, but the argumentation also contained aspects of quality enhancement or widening of the academic horizon, although on a very general, less concrete level. The weakest rationales were the economic ones, as only the labor market related need for knowledge of international processes and foreign languages among Swedish experts and professionals working either in Sweden or abroad were thematised.

The UKÄ reports focused mainly on the internationalisation of educational content and the mobility of teachers and students. Research and researchers were very little discussed, which also seems to have been the general case in the 1970 s discussions. When Jan Annerstedt in 1972 described investments, planning and control over the Swedish research landscape, he did not touch upon international collaborations, organisations, knowledge transfer or mobility. ${ }^{32}$ The research landscape was still perceived as primarily a national issue.

\section{0s and -90s: Turning towards a knowledge driven economy}

It became the task of the UKÄ, renamed in UḦ̈ (Universitets- och högskoleämbetet) to implement the recommendations of the internationalisation inquiry. For this the agency created a four year action program for internationalisation. This program aimed at supporting international perspectives and specialisations within higher education including capacitation of university teachers in general as well as a special focus on integrating language studies in general exams. The third aspect was supporting international exchange between universities and the establishment of positions for visiting teachers. ${ }^{33}$ Concrete changes the UHÄ had in mind were the establishment of international secretariats at the universities as well as the creation of a national centre for language pedagogy. ${ }^{34}$

31 Inger Andersson and Lars Sundgren, Undervisningens internationalisering (Umeå: SIDA och Fortbildningsavdelningen i Umeå, 1977); Wit J. Wojtowicz, Internationalisering $i$ lärarutbildningen (Linköping: Arbetsgruppen för internationalisering av lärarutbildningen vid universitetet i Linköping, 1985).

32 Jan Annerstedt, Makten över forskningen: Om statlig forskningsorganisation och forskningsplanering $i$ dagens Sverige (Staffanstorp: Cavefors, 1972).

33 Susan Opper, “Internationalisera högskolan! En rapport från överläggningar 27-28 februari 1980 om åtgärder för att främja högskolans internationalisering," (1980), 10-11.

34 Ernst Erik Ehnmark, "Mobility of University Staff and Students: Some Comments and Suggestions from the Swedish Viewpoint. Paper Prepared for the CRE Conference in Genoa, October 1980" (1980). 
Not only did this action program never fully materialise, due to lack of government funding. In a 1980 report the UHR concluded that Swedish universities had not taken the guidelines of the internationalisation inquiry seriously and had used the extra money received for study tours, to invite foreign researchers and for teaching abroad. ${ }^{35}$ This although the intentions had been to enhance mobility of younger Swedish researchers. Another problem according to the report was the strong focus on contacts with Anglophone countries, contrary to the recommendations in the internationalisation inquiry's final report. ${ }^{36}$

During the 1980s one can see two competing views on internationalisation, which were related to the relation between economic internationalisation and the internationalisation of higher education. In her introduction article to the UHÄ-funded book on internationalisation Gränslös högskola ("borderless university," 1981) Susan Opper treated the internationalisation of the Swedish industry and economic life in general as a negative aspect of globalisation. The movement of industrial production from Sweden to other countries were by trade unionists seen as a threat towards the "democratisation of working life" and the "production for societal needs." Internationalisation thus raises Swedish dependence on processes taking place outside the country borders and the educational sector should prepare students for this new reality. ${ }^{37}$

If the economic internationalisation was presented as a problem, then immigration and multiculturalism were described in positive terms. Without further explanation Opper stated that cultural heterogeneity actualised the need for internationalisation of higher education, the school sector and consequently of the systems for health and social security. This should be no problem, as the presence of immigrants in Swedish society meant that "resources for internationalisation" were already at hand. ${ }^{38}$ This is obviously a circular argument but seems to have been valid at the time. In the end Opper argued that internationalisation was part of the "moral obligation" of western countries to "cure ethnocentrism" and work for a future welfare through global collaboration; in the end this was a repetition of the ideas brought forth in U68 and the internationalisation inquiry. ${ }^{39}$

Another representative for the same government agency had a slightly different take on internationalisation than Opper. At the CRE conference in Genoa in October 1980 Ernst Erik Ehnmark from the international secretariat of the UHÄ presented the final evaluation report of Swedish internationalisation ${ }^{40}$ as well as a revised action program focusing on staff mobility. His speech marks an interesting shift in Swedish internationalisation policy as the needs of Swedish science were presented as one of the main reasons for enhancing mobility:

Mobility of staff and students will probably be a more and more important function of the international dissemination of specialized knowledge. No country and no university

\footnotetext{
35 Opper (1980), 13.

36 Marianne Hildebrand, Användningen av internationaliseringsmedlen vid universiteten och högskolorna 1977/78 och 1978/79 (UHÄ-rapport 1980:7, Stockholm: UHÄ, 1980), 25-26.

37 Susan Opper, "En yttre ram," in Gränslös högskola, ed. Susan Opper (Vällingby: Liber Utbildningsförlaget, 1981), 15-17.

38 Opper (1981), 17-18.

39 Ibid., 20-23.

40 Hildebrand (1980), 25-26.
} 
can any longer keep its research up to the frontiers of knowledge in all subjects or in all scientific areas. The exchange of knowledge is very much a question of personal contacts and personal communication. From this viewpoint, mobility for postgraduate students, young scientists and university staff will become more necessary than perhaps ever before. ${ }^{41}$

A similar argumentation was presented by the Swedish university chancellor Carl-Gustaf Andrén, the highest official of the UHÄ, in a speech in Uppsala in September 1980. This speech can be seen as an example of a shift in rhetoric between the 1970 s and the 1980s. Andrén started with the need for international perspectives in higher education as such and the needs for knowledge about foreign conditions for workers in development aid and export companies, but also for professional groups in Sweden. Mentioned were schools, state administration, social welfare and trade. These were arguments also present in the internationalisation inquiry reports. Andrén then formulated three overall motives for internationalisation: quality, competitiveness and solidarity. Quality meant that the quality of Swedish education should meet "highest international standards." Competitiveness meant on the one hand the transformation of knowledge into products. On the other the chancellor also stated that Swedish know-how as such could be regarded a not unimportant export product. Solidarity at last was related to quality of education, as only knowledge and insights given through high quality education made solidarity possible..$^{42}$ It is obvious that Andrén here added a new line of argument to the one present in the internationalisation inquiry. Internationalisation were from now on not only a question of solidarity through education or mobility for personal development, but also crucial for the advancement of both the economy and science itself. This means that Andrén here touched upon something that would become a strong future argument in favour of internationalisation: its importance for the creation of a research sector and in the end an economy fit for international competition.

What can also be seen in Andréns speech is an early example for an idea which came to be dominant during the period, namely the idea of the knowledge society. Nico Stehr stated in 1998 that the "transformations of modern economy" intensified the role of knowledge as an "element of production." Stehr continued:

Knowledge not only becomes an object of commercial enterprises and exchange but also is increasingly the crucial source of added-economic value and therefore of the possibility of economic growth; and, perhaps, especially sustainable economic growth ${ }^{43}$

Following this line of argument, universities as both knowledge producing and knowledge disseminating institutions, had to be central entities in a functioning knowledge society. ${ }^{44}$ Future innovations and national economic growth depended

41 Ehnmark (1980), 6 .

42 Carl-Gustaf Andrén, "Högskolans internationalisering: En uppgift för 80-talet" (September 22, 1980).

43 Nico Stehr, "The University in Knowledge Societies," Social epistemology 12, no. 1 (1998), 33-42; See also Nico Stehr, "Modern Societies as Knowledge Societies," in Handbook of Social Theory, ed. Georg Ritzer and Barry Smart (London: Sage, 2001), 494-508.

44 Stehr (1998); Jussi Välimaa and David Hoffman, "Knowledge Society Discourse and Higher Education," Higher Education 56, no. 3 (2008), 265-85. 
on the quality of higher education and research. From this point of view internationalisation became a quality driving measure, even a necessity for future prosperity. An example for is the book whose Swedish title translates to "Towards an academic education fit for international competition." ${ }^{45}$ Published in 1990 by the economist and former rector of the Gothenburg business school, Ulf af Trolle, this book argues that the quality of Swedish higher education and research was of crucial importance for national prosperity and that reforms of the organisation and funding of the sector were a necessity to obtain and maintain an international standard. It is not possible nor necessary to discuss the proposals of af Trolle in detail, it is however interesting to note, that the international arena was the explicit yardstick towards which Sweden should be measured and that future prosperity depended on how well the country fore in the international competition.

This view on internationalisation transformed into politics. Sverker Sörlin describes the research policy of the early 1990 s as "[...] a massive government support for national growth oriented, although internationally embedded research collaboration." ${ }^{46}$ His analysis of the government research propositions of the early 1990s show how fundamental the idea of knowledge and research-intensive industries was in the research policy of the time. The creation of "centres of excellence" where research and industry could interact and create new products and processes was one way to enhance and accelerate the innovation process. Another was the attraction of international researchers and a third the access to supra-national research infrastructure and networks, especially through the European union. ${ }^{47}$ International research infrastructure had of course existed and been important to research long before the $1990 \mathrm{~s}^{48}$ but they gained increased attention through the idea of a knowledge driven economic development.

Another aspect of internationalisation was the so called global questions. In his book on Swedish research policy Olle Edqvist states that polar research, energy supply or environmental issues, were an important part of government research propositions from 1986 and onwards. ${ }^{49}$ Compared to the 1970 s, where focus had been on education, the 1980s and -90s focused internationalisation of research. Where the 1970s had stressed the need for Swedish education in other countries and the Swedish students need for knowledge of foreign conditions, the late 1980s and 1990s stressed exchange of ideas, interaction and innovations. A typical example for this was a conference that the private foundation Wenner-Gren Center held in 1985, entitled "Research without borders." Here both theoretical and highly practical aspects of the internationalisation of Swedish research were discussed, such as the integration of guest researchers, problems related to research in Sweden and abroad, or research in relation to development assistance. ${ }^{50}$

45 Ulf af Trolle, Mot en internationell konkurrenskraftig akademisk utbildning (Lund: Studentlitteratur, 1990).

46 Sörlin (1994), 255.

47 Ibid., 251-54.

48 See for instance Edqvist (2009), 61-68.

49 Ibid., 55-59.

50 See Forskning utan gränser: Ett symposium om universiteten och forskningens internationalisering, ed. David Ottoson (Stockholm: Liber, 1986). 
Roughly ten years later the idea of internationalisation for international competition was a standard argument. In 1998 the government agency for higher education, Högskoleverket (Short: HSV, the successor of the UHÄ), presented a report on what the agency called strategic internationalisation. ${ }^{51}$ The opening discussion on internationalisation in this report is interesting, as it shows a dual understanding of how globalisation and the new international environment should steer the internationalisation efforts in higher education and research. ${ }^{52}$ The report starts by stating that "Sweden needs the world more than the world needs Sweden" and this was presented as the main reason for enhancing internationalisation as the new generations need more knowledge on global issues. They must, the report states, "feel at home in the wide world," but also handle changes in Sweden, such as the growing multi-ethnic character of Swedish society. So far, the arguments from the 1970 s internationalisation inquiry are clearly recognisable. The description of the current state of affairs then presented the international environment as highly competitive. The globalised economy affected nation states productivity and export while financial capital moved more easy over nation borders, making it harder to control. At the same time there was a global competition on knowledge related to new technologies, as well as an emerging global market for higher education. This is a description of a highly competitive situation, where states compete within research and knowledge production, production, export and economic growth as well as about students and researchers. At the same time the report argued heavily for the need for international collaboration. Only so could global issues, such as the economic differences between countries, environmental problems or health issues be addressed and solved on a global scale. Enhanced international collaboration was also a way to combat emerging regionalism, nationalism and religious fundamentalism as well as preventing ethnic and religious conflicts.

Using the rationales of de Wit to analyse the development between 1980 and 1998 it is clear that there had been a shift both in the arguments brought forward in favour of internationalisation and in how these arguments related to each other. Within the foreign policy rationale we see the question of technical assistance losing importance over time, whereas peace and mutual understanding were still championed. The conclusion that international collaboration was necessary to combat regionalism, fundamentalism et cetera is an argument moving into the realm of security policy, something not really present in the earlier period. Cultural aspects were weakened as arguments for individual development, adding an international dimension to teaching or widening of the academic horizon were still present, but not as prominent as during the 1970s. The reason for this was the stronger focus on the academic rationale, as meeting international academic standards and quality enhancement in order to be able to compete internationally became increasingly important.

The most notable change however is related to the economic rationales. As shown the 1980 s and -90s were a period where internationalisation of higher education and research were considered a main factor behind economic development, and in the end as something benefitting national wealth. This meant that the focus of internationalisation policy shifted from education to research and from students and teachers

51 Högskoleverket, Utbildning och forskning för strategisk internationalisering: Redovisning av ett regeringsuppdrag (Stockholm: HSV, 1998).

52 The following description is based on Högskoleverket (1998), 15-24. 
to researchers. This also made the question of formalised international collaboration within the so-called global questions or around research infrastructure a feature within Swedish internationalisation policy. Placing knowledge production and higher education at the core of economic growth also meant that international competition was considered a natural feature of higher education and research, where institutions were competing globally for research breakthroughs and about the best and brightest among researchers and students. This is a radical shift compared to the 1970 s and early 1980s with its focus on international collaboration and solidarity as ways to counter or ease the consequences of economic internationalisation.

\section{0s: Commodification of education and recruiting qualified labour}

The assumption of a knowledge driven economic development and the focus on international competition continued to be fundamental for Swedish authorities understanding of internationalisation in the new millennium as well. There were however two major changes or additions taking place between roughly 2005 and 2018, both related to mobility. A suitable starting point for understanding this development is the 2005 report from HSV on local university policies and practices which described the universities overarching aims with internationalisation in the following five points:

1. Enhancing academic quality

2. Education for an international labour market

3. Enhancing the competitiveness of Swedish higher education and research

4. Working for international peace and solidarity

5. Understanding for other cultures ${ }^{53}$

These five general aims had not changed compared to previous periods. Focus was on academic quality and competitive higher education and research, labour market needs and solidarity, peace and understanding. The report then moves on to in detail analyse ongoing work with internationalisation, and also here most things are recognisable from earlier periods. It was about internationalisation of the curricula, integrating exchange students, enhancing outgoing mobility and the creation of international research environments. Looking closer into the report however there was also something new being discussed, namely the active recruitment of foreign ("international") students to educational programs. It was stated that this phenomenon is fairly new to Sweden, but that most universities planned to intensify this in order to "strengthen their position in the international science and education society" and to attract the "best international students to masters education and then eventually to a PhD-program." ${ }^{54}$ How many $\mathrm{PhD}$-students that had been recruited this way was not known but the report suggested that statistics on foreign students degrees and country of origin should be gathered systematically in order to focus eventual future recruitment campaigns..$^{55}$

53 Högskoleverket, En gränslös högskola? Om internationalisering av grund- och forskarutbildning (Stockholm: HSV, 2005), 26.

54 Högskoleverket (2005), 99.

55 Ibid., 124. 
In 2008 the HSV made a follow up to the 2005 report. Before analysing the Swedish development, the agency made a description of general global trends within internationalisation, and something that was noted was the rapid global increase of active student recruitment. The agency saw several reasons for this: higher education had not only become an important part of global commerce (commodification), but "[...] more countries today are dependent on immigrated labour with higher education. ${ }^{56}$ Discussing mobility in the Swedish context the agency then came to the conclusion that there were market reasons for intensified campaigns for recruiting foreign students to Sweden. The amount of freemover-students globally were estimated to rise, but so was the competition for them as well. ${ }^{57}$

This shift in how to view student mobility was not only present in HSV reports, but also in central government policies. In 2006 the Swedish government created a globalisation committee (globaliseringsrådet) under the minister of education Lars Leijonborg. In its final report, also released in 2008, the same year as the HSV follow up, one of the policy recommendations of the committee was to make Sweden a net exporter of educational services. Related to this was a stronger focus on marketing activities, making Sweden attractive as a study destination..$^{58}$ The committee also thematised what it called "competition for talents." This was motivated by a perceived future demographic imbalance in the country, where an aging population was to be provided for by a shrinking active work force. The solution to this was to foster the immigration of skilled labour: "To preserve growth and welfare most countries in Europe need immigration of people who can fill gaps in the labour market and contribute with special talents." 59

The globalisation committee had not linked the perceived need for skilled labour to the mobility of students, but roughly ten years later this is exactly what was done. In 2017 the government appointed a new internationalisation inquiry, whose instructions it was to develop a new national strategy for higher education and research, to investigate how more students could get an international perspective in their education and how Sweden could be made more attractive as a study destination and a knowledge nation. ${ }^{60}$ The instructions also thematised why internationalisation was important for the rest of society. Mentioned were the international transfer of knowledge, overcoming global challenges, the importance of higher education for innovation and economic growth, as well as mutual understanding and individual development. But new was the relation between student mobility and the needs of the labour market:

By attracting researchers, experts and foreign students who stay on after completing their studies, a country can gain access to international expertise, compensate for inadequate domestic education capacity, support innovation and the economy by renewing the knowledge and innovation system through an inflow of new methods, perspectives and technologies and mitigate the effects of an ageing population. ${ }^{61}$

56 Högskoleverket, En högskola i världen: Internationalisering för kvalitet (Stockholm: HSV, 2008), 16. 57 Högskoleverket (2008), 59-60.

58 Ds 2008:82: Sverige i världen: Rapport från globaliseringsrådet (Stockholm: Fritze, 2008), 15.

59 Ibid., 19.

60 SOU 2018:3: En strategisk agenda för internationalisering: Delbetänkande av utredningen om ökad internationalisering av universitet och högskolor (Stockholm: Norstedts juridik, 2018), 31.

61 Ibid., 33-34. 
Attracting foreign students was, as one can see, of double importance for the Swedish state. Ever since the introduction of tuition fees in $2011^{62}$ paying students were a direct income to state finances. They were also considered a group among which to recruit the highly educated specialists ("talents") who were to keep Swedish growth and welfare at a high level. It is therefore not surprising that of the two inquiry reports the first one dealt with strategic aspects and internationalisation at home, whereas the second one was exclusively dedicated to changes in the systems related to skilled immigration such as study visas, residence permits for skilled workers, scholarships for students and researchers or marketing efforts for Sweden as a study destination. ${ }^{63}$ There was also pressure on the government from employer organisations, as illustrated by a 2016 report from Almega, the employer organisation for companies in the service sector, where foreign students were presented as a crucial recruitment basis for a number of service sectors. ${ }^{64}$

Parallel to this focus on attracting foreign students, higher education and research as development assistance returned as an important factor behind internationalisation of higher education in Sweden. Research collaboration and education in relation to development issues was of course as old as the idea of internationalisation, as seen at the beginning of this paper. In a way the 2000s therefore presented a return to the origins. What was new however, was the idea of a knowledge driven economic development. The societal development depends to a lesser extent on traditional production of capital and goods and to a higher extent on qualified knowledge and skills, as it was formulated in the government inquiry into higher education within development cooperation. ${ }^{65}$ Enhancing higher education, the report states, is related to an overall positive development for economic growth, entrepreneurship, leadership and social mobility in a society. In a wider context it makes citizens more well informed and therefore also enhances democratic development, civil society, tolerance and equality. ${ }^{66}$ This however redefined the relation between the developed and the developing world in how knowledge was to be transferred and by who. The $1970 \mathrm{~s}$ internationalisation inquiry had conceptualised aid as something mainly brought to the needy by Swedish development workers active abroad. ${ }^{67}$ The new deal was to focus on the education of actors from the aid-receiving countries, and to establish institutional partnerships between Swedish and foreign higher education institutions, besides the still existing technical assistance. ${ }^{68}$

62 André Bryntesson and Mikael Börjesson, Internationella studenter $i$ Sverige: Avgiftsreformens påverkan på inflödet av studenter (Stockholm: Delegationen för migrationsstudier, 2019).

63 SOU 2018:78: Ökad attraktionskraft för kunskapsnationen Sverige: Slutbetänkande av utredningen om ökad internationalisering av universitet och högskolor (Stockholm: Norstedts juridik, 2018).

64 Almega, Attrahera och behålla: Fler internationella studenter för minskade kompetensbrister (Stockholm: Almega, 2016).

65 Ds 2011:3: Högre utbildning $i$ utvecklingssamarbetet: En analys av högre utbildning inom ramen för svenskt utvecklingssamarbete och politiken för global utveckling (Stockholm: Fritze, 2011), 9.

66 Ibid., 11-14.

67 Mobility scholarships for the "third world" were however suggested by the inquiry and later also realised by the Swedish state. See Andreas Åkerlund, Public Diplomacy and Academic Mobility on Sweden: The Swedish Institute and Scholarship Programs for Foreign Academics 1938-2010 (Lund: Nordic Academic Press, 2016), 92-97.

68 Ds 2011:3, 72-73. 
Returning to the rationales of de Wit most of them maintain valid arguments in favour of internationalisation also during this period. Within foreign policy rationales technical assistance made a comeback as a central feature alongside relation building for international peace and security. Mutual understanding and personal development were still central cultural rationales. Within the academic rationales there was little change in relation to the previous period as enhancing academic quality, institution-building, and adding an international dimension in teaching et cetera were still the central arguments in favour of internationalisation.

It is, once again, within the economic rationales that the fundamental change is found. Here the basic argument about economic growth was still central. New however were two other arguments, namely that higher education was a commodity, making it necessary to actively recruit foreign students into the Swedish system, as well as the labour market related argument that foreign students should stay on in Sweden to fill the need of the labour market for skilled labour. This was a turnaround from earlier periods. If the earlier focus had been on educating students in the Swedish higher education system for an international or at least internationalised labour market, then the new deal was to consider students partly educated abroad as a resource for the domestic labour market.

\section{Conclusion: Swedish internationalisation policy from a competition state perspective}

The development of Swedish internationalisation policy started with education for international development and international solidarity in the 1970s, adding themes of research quality and international competition in the 1980s, a theme that was underpinned by the 1990s argument that higher education and research were of crucial importance for economic growth and innovations. ${ }^{69}$ During the 2000s two new strains of economy-related arguments were added: one hailing higher education as an important product, to be offered and sold on the international educational market, and one arguing that the recruitment of international students was not only of importance for the university sector, but for the needs of the domestic labour market in general.

Thus, the answer to the question why Swedish universities needed to be internationalised differs over time. Foreign policy has been a central feature from the start, with security policy-related relation building as well as technical assistance as the central arguments. Student or individual oriented arguments, such as international perspectives in the curriculum, personal development or the horizon-widening knowledge of other cultures were also constant arguments in favour of internationalisation. The same goes for the claim that internationalisation benefits world peace and mutual understanding. Academic rationales related to quality enhancement or widening the academic horizon gained weight over time, especially the line of argument that the purpose of internationalisation was to enhance the quality of higher education became especially prominent during the late 1980 s and 1990 s. This in turn was related to the development within the economic rationales, which are the ones showing the most complex development.

69 This development is also noted by Sverker Sörlin. See Sörlin (1994), 251-57. 
In the inquiries from the 1970s the importance of internationalisation for the labour market was conceptualised as a need for Swedish students, or at least students on Swedish universities, to prepare for an increasingly international labour market. The movement of both persons and knowledge was conceptualised as outgoing, from Sweden to the abroad. Foreign students contributed to the international ambient at the universities - whatever that means - but that was also their sole function. When knowledge production and innovation were made central features within the knowledge-based economy, as it was formulated from the late 1980s and onward, the view on foreign students and researchers shifted. The relation was in a way reversed as it was stated that Swedish universities needed international contacts and collaborations and the knowledge they generate in order to stay relevant and competitive, both within the inner-scientific world, as well as within the global economy as a whole. This idea that "Sweden needs the world more than the world needs Sweden" was consolidated during the 2000s as the introduction of study fees for non-EU/ EES-students made foreign students a source of revenue. The outspoken intention to recruit qualified labour for the domestic labour market among former students also reversed the 1970s view on the relation between Swedish education and international labour. Instead of educating Swedes for an international labour market, the aim was now to educate foreigners for the Swedish.

The answer to the question which the main reasons for internationalisation has been is therefore that these have shifted over time from foreign policy and cultural rationales towards academic and economic rationales. The turning point here being the idea of the knowledge society and the relationship between higher education and research, innovations and general economic growth. This economist view received yet another layer through the commodification of higher education itself through study fees and the interest in foreign students as a recruitment pool for skilled labor.

It is interesting to note that the arguments in favour of internationalisation of higher education and research can be grouped in, what it looks like, two opposing lines of argumentation. One of them is competition oriented, focusing the rapid globalisation of the economy, and arguing that internationalisation is necessary for industrialised societies in maintaining their level of development. Internationalisation develops science, economy and industry alike. Central subthemes in this line of argument is that education is an important commodity, to be sold internationally and that foreign students also present an opportunity for domestic companies to recruit highly skilled laborers.

The other line of argument is collaboration oriented. Globalisation also presents humanity with the possibility to address global challenges and the internationalisation of higher education and research is one way to create the possibilities for this. The overarching idea that positive societal development is knowledge driven is also presented as a strong argument in favour of internationalisation. Almost any desired improvement, be it economic growth, technological development, sustainability, democratisation, or equality, is helped by more internationalisation. This also explains why higher education and research, once again, becomes so strongly connected to development assistance during the 2000s.

What these two positions have in common is of course that they both present arguments in favour of internationalisation, although with underlying differences concerning which needs are to be addressed. A general trend in all documents analysed 
in this article is that very few of them, if any, address whether there could exist fundamental problems with an increased degree of internationalisation. In the end, internationalisation is always beneficial, be it for the individual person, for the development of science and higher education, for the economy, and, not to forget, for global understanding and world peace.

Returning to the idea of the competition state it is striking that some fundamental aspects of this theoretical concept, set out to explain how this new kind of state functions are easily found within Swedish internationalisation policy. The short answer to the question how this development can be understood in the light of a general development in state functioning from the traditional welfare state to the present-day competition state is that internationalisation has increasingly been about making society 'fit for competition', to use the words of Genschel and Seelkopf.

This short statement needs a longer explanation. As mentioned above the focus of internationalisation policy has been on different aspects or areas of higher education and research, depending on how the relation between the national and international has been understood. When in the 1970s Swedish students should be prepared for an increasingly international and internationalised labour market, this international environment was exclusively understood in positive terms. The idea of a knowledge driven economic growth of the 1990s however placed higher education and research at the heart of economic development and the wealth of the nation, but it also made other nations into competitors. One sign for this was the idea that Sweden should compete internationally about the "best and brightest" among foreign students and researchers. Both examples mentioned above illustrate a central aspect of the competition state, namely the declared openness towards international flows, be it capital, goods or people. ${ }^{70}$ Part of this ideology is that diversity itself is declared a productive resource, a position which is visible in the outspoken goal to create international environments at Swedish universities.

The competition state also favours openness towards international markets as visible in the 2011 tuition fee reform, which turned Swedish higher education into a commodity for non EU/EES-residents. Sweden entered the international market of higher education fairly late. Internationally foreign students had been an important source of revenue for a longer period of time. It is estimated that foreign students contributed $\$ 18.8$ billion to the US economy in the academic year $2009 / 10$ alone. ${ }^{71}$ Previous research on higher education often point to the increased marketisation and commodification of the field. ${ }^{72}$ The international trend towards commodification of higher education is best illustrated through the inclusion of educational services in the GATS-agreement ${ }^{73}$ which in turn is exactly the kind of trade

70 Genschel and Seelkopf (2015), 237.

71 Laura E. Rumbley, Philip G. Altbach, and Liz Reisberg, "Internationalization within the Higher Education Context," in The SAGE Handbook of International Higher Education, edited by Darla K. Deardoff et al (Los Angeles, London, New Dehli, Singapore, Washington D.C.: SAGE, 2012), 22.

72 Nigel M. Healey, “Is Higher Education in Really 'Internationalising'?” Higher Education 55, no. 3 (2008), 333-55; Philip G.Altbach, "Knowledge and Education as International Commodities: The Collapse of the Common Good," International Higher Education 28 (2002), 2-5.

73 Rachel Brooks and Johanna L. Waters. Student Mobilities, Migration and the Internationalization of Higher Education (Houndmills, Basingstoke, Hampshire: Palgrave Macmillan, 2011), 24; Susan L. Robertson, Xavier Bonal and Roger Dale, "GATS and the Education Service Industry: The Politics of Scale and Global Reterritorialization," Comparative Education Review 46, no. 4 (2002), 472-495. 
agreement championed by modern competition states. The increased focus on international competition also reversed how the international flows of knowledge and persons was conceptualised. Surely the U68 and the 1970s internationalisation inquiry thematised incoming students and teachers, but their focus was still on Sweden as a sender and international helper. This changed over time as focus successively moved towards Sweden as a receiver. First of knowledge, students and researchers, and then of revenue through tuition fees and of skilled foreign labour.

The marketisation of higher education is a sign for the competition state reliance on market solutions. In this case the international competition for ideas, (paying) students, researchers and "talent," was to speak up to the needs of Swedish export industry and to solve a domestic shortage in the labour force. This however did not mean that the state left internationalisation to the market. As noted by Cerny the restructuring of the state does not necessarily lead to less state or a decline of state action. Instead there is "intervention and regulation in the name of competitiveness and marketisation." 74 Swedish internationalisation policy during the 2000 s has in much been about regulation of international flows and contacts, in setting up rules for tuition fees, systems for mobility and international collaboration, and linking the internationalisation of higher education to shortages on the labour market. Future research should look more into the institutional and organisational aspects of this process, such as government funding to international collaboration, mobility or curriculum internationalisation or internationalisation at home.

Jürgen Enders mentions that globalisation is a phenomenon which challenges the idea of the nation state, but he remains unclear when it comes to how we should understand this challenge. ${ }^{75}$ Genschel and Seelkopf make a similar observation and state that globalisation and the transformation towards a competition state result in a decline of state sovereignty. ${ }^{76}$ International trade treaties and the constant risk that mobile capital leaves the country makes it hard for governments to pursue protectionist or decommodification politics. Something similar is of course true of mobile students, researchers and skilled professionals, who will eventually leave if education or the job market is not what they expected, or better prerequisites for research can be found elsewhere.

The development of internationalisation as a policy area is how the Swedish state has handled this political situation and the risks connected to it. Although the creation of Swedish internationalisation policies from the 1970s and onwards have been concerned with different areas and have had different motives, the overarching aim has always been to enhance internationalisation. There is therefore no opposition or antagonism between the collaborative and competitive aspects of internationalisation policy mentioned above. Both are ways to expose the national system of higher education and research to international influences.

In a competition state, internationalisation of higher education and research-be it collaborative or competitive-can therefore be understood as an important way in which the new relation between the national and the global is both formulated and realised. It is worth returning to the following quote from Philip G. Cerny:

74 Cerny (1997), 251.

75 Enders 2004, 369.

76 Genschel and Seelkopf (2015), 240. 
[T]he state still has a major national role to play, but that role is increasingly to expose the domestic to the transnational, to prise open the nation-state to a globalizing world, in the interest of ensuring that citizens keep up with the multiple pressures and demands of that increasingly integrated and interdependent political, economical and social ecosystem. The foreign or external is no longer external or 'outside'. It is internalized in the very way the state operates and people interact politically, economically and socially from the local to the global levels. ${ }^{77}$

Internationalisation policy and measures are therefore really a way to ensure that the national system of higher education and research gets exposed to the transnational. It makes it possible for citizens, both domestic and foreign, to keep up with the demands of an increasingly globally interdependent economy and society. And above all internationalised curricula, collaboration schemes or in- and outgoing mobility of persons, are definitely a way to internalise the foreign or external on a national level, both keeping education and research open to international influences while at the same time trying to regulate this openness in order to fare well in an international environment, primarily understood as competitive.

77 Cerny (2010), 6. 


\section{References}

Almega. Attrahera och behålla: Fler internationella studenter för minskade kompetensbrister. Stockholm: Almega, 2016.

Altbach, Philip G. "Knowledge and Education as International Commodities: The Collapse of the Common Good." International Higher Education 28 (2002), 2-5. Andersson, Inger and Lars Sundgren. Undervisningens internationalisering. Umeå: SIDA och Fortbildningsavdelningen i Umeå, 1977.

Andrén, Carl-Gustaf. "Högskolans internationalisering: En uppgift för 80-talet." September 22, 1980. Riksarkivet [Swedish National Archives], UHÄ, 1976-83, IS, F1D, vol. 1.

Annerstedt, Jan. Makten över forskningen: Om statlig forskningsorganisation och forskningsplanering $i$ dagens Sverige. Staffanstorp: Cavefors, 1972.

Ben-David, Joseph and Awzaham Zloczower. "Universities and Academic Systems in Modern Societies." In: Joseph Ben-David, Scientific Growth: Essays on the Social Organization and Ethos of Science, edited by Gad Freudenthal, 125-57. Berkeley: University of California Press, 1991.

Brissman, Henrik. Mellan nation och omvärld: Debatt i Sverige om vetenskapens organisering och finansiering samt dess internationella och nationella aspekter under 1900-talets första hälft. Lund: Lunds universitet, 2010.

Broady, Donald, and Mikael Börjesson. "How to Investigate Cross-Border Phenomena: Some Conceptual and Terminological Issues." Paper presented at Power, Cosmopolitanism and the Transformation of European Elites, Trinity College Dublin, June 8-9, 2015.

Brooks, Chay. "'The Ignorance of the Uneducated': Ford Foundation Philanthropy, the IIE, and the Geographies of Educational Exchange." Journal of Historical Geography 48 (2015), 36-46.

Brooks, Rachel and Johanna L. Waters. Student Mobilities, Migration and the Internationalization of Higher Education. Houndmills, Basingstoke, Hampshire; New York: Palgrave Macmillan, 2011.

Bryntesson, André and Mikael Börjesson. Internationella studenter i Sverige: Avgiftsreformens påverkan på inflödet av studenter. Delmi-rapport 2019:4, Stockholm: Delegationen för migrationsstudier, 2019.

Buckner, Elizabeth S. "The Changing Discourse on Higher Education and the NationState, 1960-2010." Higher Education 74, no. 3 (2017), 473-89.

Cerny, Philip G. "Paradoxes of the Competition State: The Dynamics of Political Globalization." Government and Opposition 32, no. 2 (1997), 251-74.

Cerny, Philip G. "The Competition State Today: From Raison d'État to Raison du Monde." Policy Studies 31, no. 1 (2010), 5-21.

de Wit, Hans. Internationalization of Higher Education in the United States of America and Europe: A Historical, Comparative and Conceptual Analysis. Westport: Greenwood Press, 2002.

Ds 2008:82: Sverige i världen: Rapport från globaliseringsrådet. Stockholm: Fritze, 2008.

Ds 2011:3: Högre utbildning $i$ utvecklingssamarbetet: En analys av högre utbildning inom ramen för svenskt utvecklingssamarbete och politiken för global utveckling. Stockholm: Fritze, 2011.

Edqvist, Olle. Gränslös forskning: Om internationaliseringen av svensk forskning. Nora: Nya Doxa, 2009. 
Ehnmark, Ernst Erik. "Mobility of University Staff and Students: Some Comments and Suggestions from the Swedish Viewpoint. Paper Prepared for the CRE Conference in Genoa, October 1980." Riksarkivet [Swedish National Archives], UHÄ, 1976-83, IS, F1D, vol. 1.

Elzinga, Aant. "Universities, Research and the Transformation of the State in Sweden." In: The European and American University since 1800: Historical and Sociological Essays, edited by Sheldon Rothblatt and Björn Wittrock, 191-233. Cambridge: Cambridge University Press, 1993.

Enders, Jürgen. "Higher Education, Internationalisation and the Nation-State: Recent Developments and Challenges to Governance Theory." Higher Education 47, no. 3 (2004), 361-82.

Forskning utan gränser: Ett symposium om universiteten och forskningens internationalisering, edited by David Ottoson. Stockholm: Liber, 1986.

Füssl, Karl-Heinz. "Between Elitism and Educational Reform: German-American Exchange Programs, 1945-1970." In The United States and Germany in the Era of the Cold War, 1945-1990: A Handbook, edited by Detlef Junker, 409-16. West Nyack: Cambridge University Press, 2004.

Genschel, Philipp, and Laura Seelkopf, "The Competition State: The Modern State in a Global Economy." In The Oxford Handbook of Transformations of the State, edited by Stephan Leibfried, Evelyne Huber, Matthew Lange, Jonah D. Levy, and John D. Stephens, 237-252. Oxford: Oxford University Press, 2015.

Global Exchanges: Scholarships and Transnational Circulations in the Modern World, edited by Ludovic Tournès and Giles Scott-Smith, Oxford: Berghahn, 2018.

Healey, Nigel M. "Is Higher Education in Really 'Internationalising'?" Higher Education 55, no. 3 (2008), 333-55.

Hildebrand, Marianne. Användningen av internationaliseringsmedlen vid universiteten och högskolorna 1977/78 och 1978/79. UHÄ-rapport 1980:7. Stockholm: $\mathrm{UH} \ddot{\mathrm{A}}, 1980$.

Högskoleverket. Utbildning och forskning för strategisk internationalisering: Redovisning av ett regeringsuppdrag. Stockholm: HSV, 1998.

Högskoleverket. En gränslös högskola? Om internationalisering av grund- och forskarutbildning. Stockholm: HSV, 2005.

Högskoleverket. En högskola $i$ världen: Internationalisering för kvalitet. Stockholm: HSV, 2008.

Johnson, Walter. The Fulbright Program: A History. Chicago: University of Chicago Press, 1965.

Jonas, Gerald. The Circuit Riders: Rockefeller Money and the Rise of Modern Science. New York: Norton, 1989.

Kim, Terri. "Shifting Patterns of Transnational Academic Mobility: A Comparative and Historical Approach." Comparative Education 45, no. 3 (2009), 387-403.

Knight, Jane. "Internationalization Remodeled: Definition, Approaches, and Rationales." Journal of Studies in International Education 8, no. 1 (2004), 5-31.

Laitenberger, Volkhard. Akademischer Austausch und auswärtige Kulturpolitik: Der Deutsche Akademische Austauschdienst (DAAD) 1923-1945. Göttingen: Musterschmidt, 1976.

Lindensjö, Bo. Högskolereformen: En studie i offentlig reformstrategi. Stockholm: Stockholms universitet, 1981. 
Ljungström Ljungström, Olof. Ämnessprängarna: Karolinska Institutet och Rockefeller Foundation 1930-1945. Stockholm: Karolinska institutet University Press, 2010.

Opper, Susan. "Internationalisera högskolan! En rapport från överläggningar 27-28 februari 1980 om åtgärder för att främja högskolans internationalisering.” 1980. Riksarkivet [Swedish National Archives], UHÄ, 1976-83, IS, F1D, vol. 1.

Opper, Susan. ”En yttre ram.” In Gränslös högskola, edited by Susan Opper, 10-30. Vällingby: Liber Utbildningsförlaget, 1981.

Proposition 1976/77:59: Om utbildning och forskning inom högskolan m.m.

Robertson, Susan .L., Xavier Bonal and Roger Dale. "GATS and the Education Service Industry: The Politics of Scale and Global Reterritorialization." Comparative Education Review 46, no. 4, (2002), 472-495.

Rumbley, Laura E., Philip G. Altbach, and Liz Reisberg. "Internationalization Within the Higher Education Context." In The SAGE Handbook of International Higher Education, edited by Darla K. Deardoff, Hans de Wit, John D. Heyl, and Tony Adams, 3-26. Los Angeles, London, New Dehli, Singapore, Washington D.C.: SAGE, 2012.

Rüegg, Walter. “Chapter 1: Themes.” In: A History of the University in Europe: Volume IV Universities since 1945, edited by Walter Rüegg, 3-30, Cambridge: Cambridge University Press, 2011.

Sassen, Saskia. A Sociology of Globalization. New York: W.W. Norton, 2007.

Scott, Peter. "Massification, Internationalization and Globalization." In The Globalization of Higher Education, edited by Peter Scott, 108-29. Buckingham: Open University Press, 1998.

SOU 1973:2: Högskolan: betänkande av 1968 års utbildningsutredning. Stockholm, 1973.

SOU 2018:3: En strategisk agenda för internationalisering: Delbetänkande av utredningen om ökad internationalisering av universitet och högskolor. Stockholm: Norstedts juridik, 2018.

SOU 2018:78: Ökad attraktionskraft för kunskapsnationen Sverige: Slutbetänkande av utredningen om ökad internationalisering av universitet och högskolor. Stockholm: Norstedts juridik, 2018.

Stehr, Nico. "Modern Societies as Knowledge Societies." In: Handbook of Social Theory, edited by Georg Ritzer and Barry Smart, 494-508. London: SAGE, 2001.

Stehr, Nico. “The University in Knowledge Societies." Social Epistemology 12, no. 1 (1998), 33-42.

Sundin, Jan. Främmande studenter vid Uppsala universitet före andra världskriget: En studie $i$ studentmigration, Uppsala: Uppsala universitet, 1973.

Sörlin, Sverker. De lärdas republik: Om vetenskapens internationella tendenser. Malmö: Liber-Hermods, 1994.

af Trolle, Ulf. Mot en internationellt konkurrenskraftig akademisk utbildning. Lund: Studentlitteratur, 1990.

U68. Mål för högre utbildning: Diskussionsunderlag utarbetat inom U 68. Stockholm: Norstedt, 1969.

UKÄ. Att internationalisera universiteten: utgångspunkter, riktlinjer och frågeställningar för en internationalisering av universitetsutbildningen. Betänkande III från UKÄ:s internationaliseringsutredning. Stockholm: UKÄ, 1973. 
UKÄ. Utbildningens internationalisering: Slutbetänkande från UKÄs internationaliseringsutredning. Stockholm: UKÄ, 1974.

Wittrock, Björn. “The Modern University: The Three Transformations. "In: The European and American University since 1800: Historical and Sociological Essays, edited by Sheldon Rothblatt and Björn Wittrock, 303-62. Cambridge: Cambridge University Press, 1993.

Wojtowicz, Wit J. Internationalisering i lärarutbildningen. Linköping: Arbetsgruppen för internationalisering av lärarutbildningen vid universitetet i Linköping, 1985.

Välimaa, Jussi and David Hoffman. "Knowledge Society Discourse and Higher Education." Higher Education 56, no. 3 (2008), 265-85.

Åkerlund, Andreas. Public Diplomacy and Academic Mobility in Sweden: The Swedish Institute and Scholarship Programs for Foreign Academics 1938-2010. Lund: Nordic Academic Press, 2016. 